\title{
SEQUENCE TWO
}

SEQUENCE 2.2 (2015)

ISSN 2052-3033 (Online)

TEXT, PARATEXT AND SUBTEXT

Reading Mildred Pierce as Maternal Melodrama

\section{Pam Cook}

\section{Contents}

TEXT, PARATEXT AND SUBTEXT

1. Trans-textual negotiations

VIDEO 1: Maternal Overdrive

2. Reading maternal melodrama: paratext and subtext

3. Maternal melodrama and tears

4. Maternal melodrama and myth: how queer is it?

VIDEO 2: Mildred's Kiss

VIDEO 3: Mildred's Kiss: A Maternal Melodrama

ACKNOWLEDGEMENT

SUGGESTED CITATION

COPYRIGHT NOTICE

REFERENCES

NOTES 


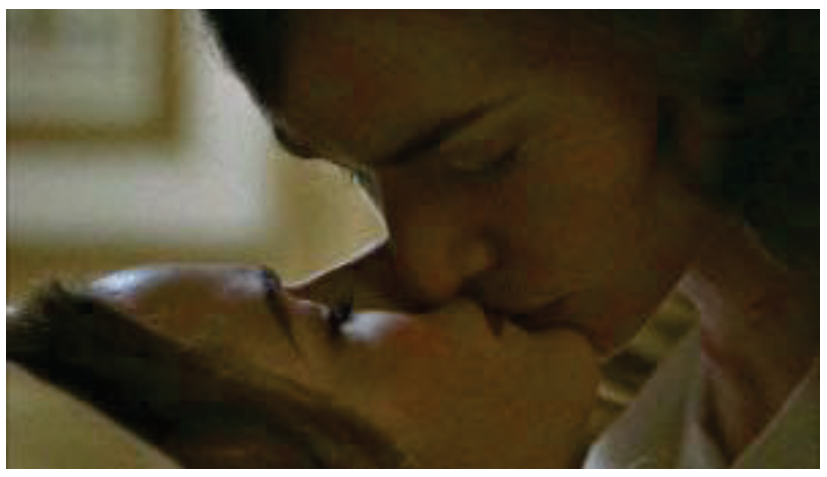

There is a substantial body of scholarly writing addressing formal, theoretical, ideological and industrial issues of melodrama, a daunting amount of which is concerned specifically with maternal melodrama. The genre has a long history in cinema and continues to inspire contemporary film- and television-makers such as Andrea Arnold (Fish Tank, 2009), Lynne Ramsay (We Need to Talk About Kevin, 2011),[1] Sally Wainwright (Happy Valley, 2014) and Todd Haynes (Mildred Pierce, 2011), who all exploit the dark side of mother-love. In these modern examples, relationships between mothers and children are ambivalent and fraught, sometimes veering into horror.[2] The persistence of stories of maternal desire, sacrifice, obsession, violence and blame suggests they touch on profound, submerged feelings and fantasies. I shall try to uncover what makes maternal melodrama culturally significant by focusing on the different versions of Mildred Pierce (novel, film and miniseries) and including one or two other titles along the way. As well as looking at written scholarship, I shall refer to my videographic work, which uses the audio-visual essay to present ideas in a particularly condensed form, blending the heightened emotions of the genre with critical commentary.

In her inaugural essay on maternal melodrama for SEQUENCE Two, Sue Thornham discusses Lynne Ramsay's critical reappraisal of mother-love in We Need to Talk about Kevin, analysing in detail the film's exploration of issues of female identity, agency and control.[3] She illuminates the importance of feminist theory and filmmaking in interrogating social and psychic structures of motherhood. I take this enquiry in a different direction to argue that feminist scholarship has largely defined the group of films we call maternal melodrama, and has determined the parameters of debate. It is not unusual for critical discourse to retrospectively construct generic movements and cycles: film noir is an obvious example. However, the operations of textual interaction and mediation involved in the processes of genre configuration are not widely discussed. I suggest that the textual fluidity characteristic of maternal melodrama presents a challenge to the ways in which we conceptualise the objects we choose to study and to accepted analytical methods. 
The framework for my discussion is the way the audio-visual landscape has transformed our experience of media objects, and how that in turn influences the nature and boundaries of those objects. Cinema has always been trans-media, but the proliferation of devices offering instant access and multiple opportunities for interaction and consumption has intensified trans-textual and cross-media exchanges. Ellen McCracken has written about the impact of transitional electronic literature on the literary text, briefly citing Jonathan Gray's study of the relationship between paratextual material and the viewer/reader's perception of films. [4] For McCracken, the literary text is radically and irrevocably shattered by the intrusion of extraneous material and interactive consumer experience into the conventional book. McCracken perhaps overestimates the consistency of more traditional reading patterns, but her argument could be developed to explore viewing activities via tablets and mobile phones, both inside and outside the cinema, where transition between different interfaces shapes reception, fracturing textual cohesion while producing new narratives. Although I do not follow that route here, its focus on fragmentation and textual mutation informs my approach, which moves away from the self-contained film towards a wider, dialogic understanding of textual production. This involves reassessment of the role of the director/auteur in textual transformation.

Part of my endeavour is to understand how we come to read films as maternal melodrama, and whether our interpretations derive from film objects or from the conjunction of wider networks of discourses. In one sense this seems to be an obvious question: it is self-evident that when discussing or analysing any texts we bring to bear knowledge and skills derived from many external sources. But the relationship between those texts and the new objects that emerge is not always recognised. To illuminate such trans-textual interactions I use the notion of paratext, a term coined by literary theorist Gérard Genette to describe the productions that surround the literary text and present it as a book of a particular kind, such as the cover, title, the author's name, a preface or introduction, and even typeface and paper.[5]

Genette confines his observations to books, but equivalent forms of presentation in films would be title design, including music, the names of the director and other key personnel, lead actors, studio logos and other information on front and end credits, trailers and adverts, all of which lead viewers towards a preferred reading, that is, preferred by the filmmakers. These paratexts, more or less authorised by the producers of texts and their agents, do not exist separately from the main film, but are positioned on its borders. In Genette's terms, they are an undecided zone that can lead inwards to the interior of the text or outwards to the exterior discourses relating to it. Significantly, he sees this fringe area as controlling the whole reading.[6] The paratexts are an integral part of the textual object, which cannot be understood without them. The 
boundary and integrity of what we think of as the film object (the first to the last shot) are changed by the idea of paratext, and so is the nature of reading methods. What we describe as context, for example, does not exist separately from, or outside the film object, but is enmeshed in it.

Genette subdivides paratexts into peritexts, which stand in close proximity to the object (in a film, titles, credits and so forth) and epitexts: interviews with directors, producers, designers, stars and others, reviews and discussions in various media, promotional materials, DVD extras and commentaries and, we might add, scholarly appraisal. Although these lie some distance from the main text and may include material that precedes it in time-for example, the novel on which a film is basedthey can be used by those responsible for producing the film in order to influence reception. Speaking in interviews about the Mildred Pierce miniseries, Todd Haynes insisted that James M. Cain's novel rather than the 1945 film was the primary source for his version. [7] He referred to feminist scholarship about the split between film noir and melodrama in the Warner Bros movie, announcing his intention to reclaim the story as melodrama.[8] This strategy transported anterior, epitextual material (the novel) into the miniseries text and directed viewers to Haynes's preferred reading. This reading was then adopted and disseminated by most critics, who presented Haynes's version as a faithful adaptation. [9]

Outside the mainstream critical response, some bloggers responded to Haynes's assertion that he had bypassed the 1945 movie by returning to that film rather than the novel and resurrecting their allegiance to it.[10] In a paper for the Mildred Pierce symposium at Bristol University in 2012, I was led by Haynes's contradictory statements that he remembered seeing and reading about the movie as a student, but had ignored or forgotten it when making the miniseries, to excavate mementoes of the 1945 version in his version, including traces of its visual style.[11] By way of epitextual material the 1945 Mildred Pierce was retrieved as subtext in the miniseries. Although this interpretation appeared to go against the director's preferred reading, Haynes had in fact laid the groundwork for it himself, ensuring that his version could be received as a text of many layers open to several readings, which could only boost his auteur credentials and enhance DVD sales.

\section{Trans-textual negotiations}

The process of textual analysis and reconstruction is complex. The reader/viewer is directed outwards (centrifugally) and inwards (centripetally) between film and paratexts in the activity of constructing a new object that we call the text. This activity can be 
concurrent with viewing the film, or take place subsequently with secondary elaborations that occur at a distance from the viewing experience. Paratexts are also textual, though they are not always treated as such. More often they are regarded as neutral carriers of information, particularly in the case of interviews, production notes and DVD commentaries. The interactions between paratexts and film objects generally appear seamless: a familiar tactic is to use a quote from an interview to support a particular interpretation as if the quote were a transparent guarantee of truth. As scholars and researchers we all do this, and I do not argue that we should not. Rather, I suggest that Genette's attention to trans-textual operations allows us to be more circumspect and self-reflexive in the ways we use such materials in research and writing.

To recap Genette's formulation, paratexts are involved in the hermeneutic process and can be seen as part of the new text that results-there is no hierarchy of texts in which the film is privileged object and surrounding discourses are secondary or subsidiary. There is no text without paratexts, and to a large extent paratexts determine the analysis. I made a two-minute video to illustrate how paratexts and film objects may work together to produce readings, using the 1949 movie directed by Max Ophüls, The Reckless Moment, which was based on The Blank Wall, a 1947 crime novel by Elisabeth Sanxay Holding.[12] The story is about a middle-class mother, played by Joan Bennett, who becomes involved in blackmail and murder as she tries to rescue her rebellious daughter from the clutches of criminals. The DVD release includes a twenty-minute featurette called Maternal Overdrive in which Todd Haynes talks about the film and his love for it.[13] He compares it to Mildred Pierce as a crossover between crime and melodrama in visual style as well as narrative and he sees it as a critique of the American family. The featurette uses paratextual material such as clips from the film, posters, production stills and other images. My video puts together a clip from the featurette and one from the film's ending running simultaneously to show the transformative effect of paratexts on the film object in the process of analysis. 


\section{VIDEO 1: Maternal Overdrive}

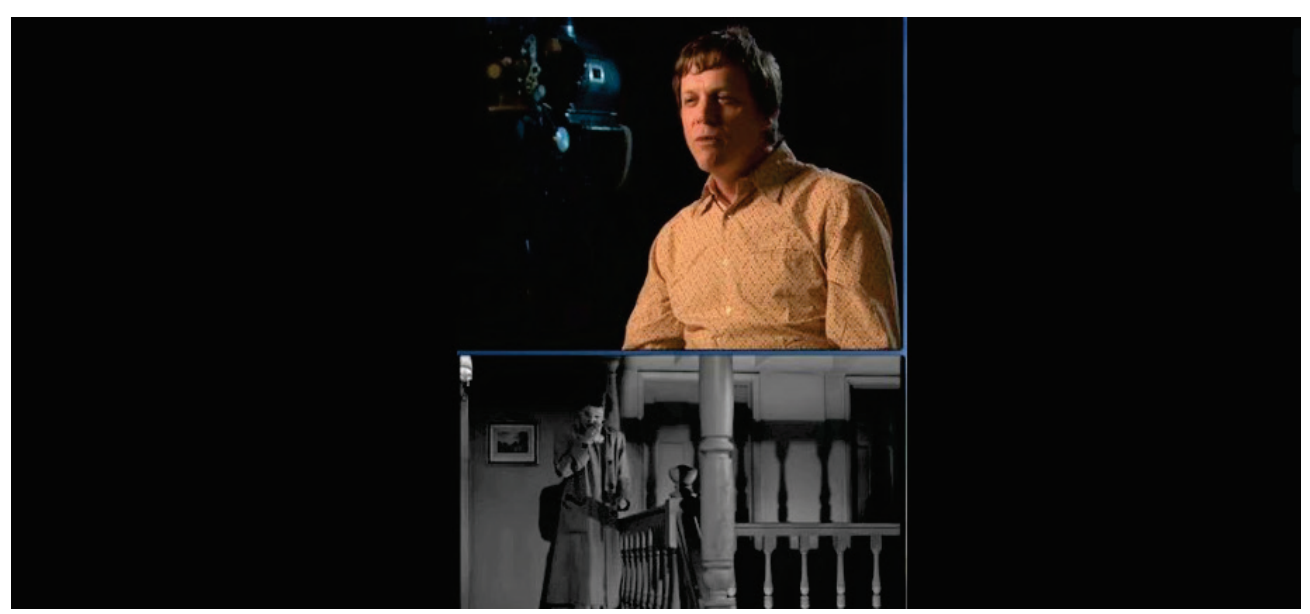

There is much to say about Haynes's reading, his use of epitexts, and his designation of the film as an auteur work. In the course of the featurette he refers to the studio context, primarily to point up Ophüls's status as a European auteur. The clip from the movie contradicts his account in some respects and alternative readings are available-but Haynes's interpretation of the ending, which occludes the crime film iconography and the studio logo, is powerful, especially to those who know and love melodrama. A new text is created; The Reckless Moment (and Haynes's work) are positioned in the tradition of sophisticated melodramas made by European auteurs working in the Hollywood studio system who offered a subliminal challenge to American ideology. The intention behind my video is to create another new object that produces a fissure in the seamless interaction between paratexts.

This allows a question to be raised about the transparency of paratextual material and invites awareness of the processes of trans-textual negotiation. The authority of Haynes's account is destabilised; it appears as performance, as self-presentation enmeshed in promotional tactics that attempt to lead viewers in a particular direction and reinforce his auteur credibility. Haynes's reading of The Reckless Moment as melodrama rather than as crime fiction is a strategy that he repeated when he came to make the Mildred Pierce miniseries. As noted, in returning to the novel he asserted his intention to rescue the story from the crime film framework added to the movie by the studio and reinstate it as melodrama. The generic uncertainty of both films is a feature of the history of screen melodrama-in the early days of scholarly work several writers asked whether melodrama could be called a genre, or was it better seen as a tendency, 
or mode that pervaded other genres.[14] This brings me back to my initial query: how do we come to define films as maternal melodrama?

\section{Reading maternal melodrama: paratext and subtext}

Genette argues that paratexts, especially those authorised or semi-authorised by producers of the work and their agents, operate to position a text as a particular kind of object in an attempt to influence reception. He acknowledges that epitexts, even those positioned at considerable distance from the object in time, can also have an impact on how texts are viewed. In her article on 1920s and 1930s maternal melodramas in Hollywood, Lea Jacobs notes the consensus of modern scholarly writing that has referred to a body of films as maternal melodrama.[15] Following Christian Viviani, who first coined the term in Les Cahiers de la Cinémathèque in 1979,[16] feminist film scholars 'interrogated maternal melodrama's representation of motherhood, and the appeal of stories of maternal suffering and self-sacrifice for women spectators'. [17] This feminist scholarship now forms a classical tradition of writing on melodrama.[18] While acknowledging the importance of this work, Jacobs points out that in the 1920s such films were not primarily understood by reviewers as women's pictures but were evaluated according to their appeal to certain markets along a rural (naive, sentimental, aimed at 'susceptible spectators') versus urban (sophisticated, aimed at the intelligentsia) divide. Mother-love stories, even big-budget quality productions featuring respected actors and directors, were increasingly perceived as old-fashioned and conservative, giving rise to a spate of modern domestic dramas that included shocking themes suitable for adult audiences and were described as having 'European' influences.[19]

Jacobs's analysis reveals that during the period she investigates, even so-called sentimental mother-love stories often pivoted on crime, featuring disputes over money, blackmail, violence and murder. There were exceptions, such as the 1925 Stella Dallas, which centred on maternal sacrifice and was considered to be more suitable for non-urban audiences. Its portrayal of the working-class mother as a pitiful, vulgar figure lacking in social graces was, however, seen as unusual and aligns the film with the emergence of what Jacobs calls the 'anti-mother plot' in theatre and film. These productions often featured themes in which the mother was depicted as psychologically unstable with an unhealthy, obsessive or hostile relationship to her children. Although this trend was not fully developed until the 1940s, partly because the transition to sound saw a short-lived revival of sentimental mother-love stories and, indeed, mother songs, it formed a significant strand in the shift towards modernised, Europeanised variants of the cycle that emerged in the late-1930s. 
Jacobs defines mother-love stories in terms of narratives that have mothers and their relationship with their children at the centre. She variously describes them in the terms used by contemporary reviewers, such as domestic dramas or tearjerkers, and also uses the phrase maternal melodramas. The examples she cites span family sagas, crime dramas, musicals and what might be called social problem pictures. They do not all appeal to the emotions: the modern adult variants in particular, even though they may depict pathos or the release of strong feelings, are attuned to intellectual or aesthetic response. Jacobs's historical investigation demonstrates that mother-love films do not cohere into a genre even though they share common features and target particular audiences. They are constituted as maternal melodrama by scholarly writing discussing melodrama as a genre and by feminist research looking at melodrama's formal attributes and ideological implications. In other words, maternal melodrama is brought into being by paratexts, or more precisely epitexts that transform the film objects into texts and become part of them. I am aware, for example, that my interpretation of the ending of Stella Dallas cannot be separated from the body of feminist work that discusses it.

The 1945 version of Mildred Pierce is also much discussed by feminist scholars whose analysis forms part of how the film is viewed by certain audiences. These epitexts were brought into closer proximity to Haynes's miniseries by his references to the film and the scholarship devoted to it. At the same time, his insistence that the 1945 film was not the source for his version, while seeming to dismiss it, gave it the power of a subtext, a hidden meaning available to be excavated. This could only happen by virtue of Haynes's paratextual references to the film and feminist scholarship because the process of excavation depends on familiarity with both. [20] Before I discuss Haynes's use of paratext and subtext in relation to the miniseries, I want to return to his comments on The Reckless Moment in Maternal Overdrive. Immediately after his remark that Ophüls's film has had a profound influence on his work and he ripped it off in Far from Heaven (2002), he says that he called the maid Sybil after the maid in Reckless Moment, making his use of that film as subtext in his own production explicit. Subtext refers to implicit meanings embedded in the text that may or may not be put there by the filmmakers and can be reconstructed by audiences in their own interests, as with queer readings for example. Haynes is adept at using paratexts to produce subtexts. In the Mildred Pierce miniseries subtext is used in various ways to create layers of meaning, such as inserting trans-textual references for viewers to pick up on closer analysis; drawing viewers in to a complex interpretive experience; and adding subtle meanings not carried by narrative and dialogue. 


\section{Maternal melodrama and tears}

I would like to speculate on the reasons for Haynes's strategy of positioning The Reckless Moment and Mildred Pierce as melodrama rather than crime drama or film noir. In interviews about the miniseries he spoke about his love for melodrama and dislike of the punitive police investigation narrative that frames the 1945 film. However, maternal melodrama is hardly less punitive-it depends on the spectacle of maternal punishment and suffering, which are exploited to full emotive effect in Haynes's miniseries. In talking about The Reckless Moment in the Maternal Overdrive clip, he describes the huge release of emotion at the end, as Joan Bennett's character Lucia lies sobbing on her bed, relieved that her family is out of danger while also aware that any possibility of escaping her domestic situation has gone. He says that he consciously recreated that moment in Far from Heaven.

In the Mildred Pierce miniseries, which also features spectacular displays of maternal suffering, there is a similar scene of copious tear-shedding at the end when Mildred/Kate Winslet's emotions spill over as Veda (Evan Rachel Wood) leaves for good after delivering a final humiliating blow to Mildred. This crying scene also occurs at the end of the novel. I am curious about the function of such displays of female sobbing in maternal melodrama. In his article 'Melodrama and Tears', Steve Neale quotes literary critic Franco Moretti on the factors in certain stories that make the reader cry. Among them are timing-the awareness that much as we would like to change the outcome of events, it is too late-and powerlessness: 'This is what makes one cry. Tears are always the product of powerlessness. They presuppose two mutually opposed facts: that it is clear how the present state of things should be changed-and that this change is impossible.' [21]

Moretti is writing about the reader's response, but his remarks resonate with the episodes of sobbing in maternal melodramas in which the mother is disempowered. Reckless Moment and Mildred Pierce both feature narratives in which mothers who take control of events subsequently lose it-this structure can be found in other maternal melodramas: All That Heaven Allows (1955) and Stella Dallas (1925/1937) spring to mind. Although these examples do not include lengthy cathartic crying scenes, they feature maternal suffering, pathos, tears and the performance of strong emotions - and the same can be said of the 1945 version of Mildred Pierce. The extended sobbing scenes to which Haynes draws attention suggest a number of things: an ambivalence towards the mother in filmmakers and viewers that induces pleasure in her distress as well as sympathy; the character's justifiable emotional response to the disproportionate punishment of her transgressive behaviour; and the painful 
recognition of her powerlessness. The intensity of the character's emotions implies that the mother's disempowerment is a significant event, and here, perhaps, lies the importance of maternal melodrama.

\section{Maternal melodrama and myth: how queer is it?}

One of the epitexts that informs my reading of Mildred Pierce is the ultimate story of maternal love and disempowerment, the myth of Demeter and Persephone. It is also a tale of incestuous desire, as many myths are. Demeter, goddess of agriculture and fertility, attempts to rescue her daughter Persephone, whose father is Demeter's brother Zeus, from the clutches of another of her brothers, Hades, who has abducted her and carried her off to the Underworld. Demeter searches for Persephone obsessively and is so overcome by grief and loss that the seasons are halted and life on earth is threatened with extinction. Zeus, ruler of the gods, intervenes to save the earth, but Hades tricks Persephone into eating pomegranate seeds so that she is bound to return to him for six months of the year. Persephone's separation from Demeter brings about the dark days of autumn and winter while the spring and summer months are those in which she is reunited with her mother.

The nineteenth-century anthropologist J. J. Bachofen, whose work influenced Friedrich Engels and Walter Benjamin among others, drew on this myth to make a case for his theory of Mother-Right, which posited the existence of a pre-historic matriarchal society that was overturned in the emergence of masculine patriarchy.[22] For Bachofen, The Demeter/Persephone myth dramatised the demise of Mother-Right, but he also saw the overturning of Mother-Right, which involved maternal sacrifice, as the foundation of civilised society. I am not concerned with the credibility or otherwise of Bachofen's thesis, but the persistence of the idea of matriarchal society in patriarchal institutions suggests a motive for the replaying of stories of maternal disempowerment in melodrama. Such stories, and the excessive emotion they generate, point to the significance of the overthrow of matriarchy in sustaining patriarchy. They also intimate the possibility of a social order governed by women while simultaneously denying it, producing the sense of loss and powerlessness that Neale/Moretti argue leads to tears.

The Demeter myth and Bachofen's theory of Mother-Right are epitexts embedded in my reading of Mildred Pierce as subtext to support my preferred reading. Together with the subtexts produced by Todd Haynes, they help to explain the cultural significance of maternal melodrama. But there is another crucial element lurking in mother-love stories, linked to the Demeter myth and crystallised in the motherdaughter love that lies at the heart of Mildred Pierce. The novel, published in 1941, the 
1945 film and the 2011 miniseries all treat the relationship between Mildred and Veda differently. James M. Cain depicts Mildred as a possessive, controlling mother whose obsession with her daughter becomes explicitly sexual. The 1945 film, as we might expect, elides this aspect of the story. Joan Crawford's Mildred is portrayed as overinvested in Veda (Ann Blyth), but the same-sex attraction implications are displaced onto Mildred's friendship with Ida (Eve Arden). Although Haynes's adaptation includes the scene in which Mildred kisses Veda on the mouth, and the one in which Veda taunts Mildred by flaunting her naked body at her, when I first saw the miniseries, it seemed to gloss over what might be called the queer aspects of Cain's novel by presenting Mildred's incestuous attraction to Veda almost as a romance and playing down her sexual rejection of her husband Monty (Guy Pearce).[23] I found this surprising, partly because of Haynes's standing as a queer filmmaker, but also because the miniseries is not shy about depicting sex (it includes an oral sex scene that is quite brave for television).

There could be many reasons for Haynes's discretion. One might be his strategic attachment to creating subtext, which I have noted. In addition, his interpretation of the story, and Winslet's expressive acting, tend to sideline the crime elements of Cain's novel, in which Mildred commits fraud to help pay for Veda's expensive lifestyle. On first viewing, the miniseries downplayed Cain's most trangressive gesture-Mildred's violation of the incest taboo-and, together with the elision of her criminal tendencies, shifted emphasis to her status as a victim of forces beyond her control. This challenged the critical consensus that Haynes had made a faithful adaptation, and it also relegated the central, crucial point of Cain's story to the level of subtext. My perception of the friction between the miniseries and Cain's novel informs my video essay Mildred's Kiss, just over a minute long, which superimposes Cain's words on Haynes's images and sounds to point up the differences.[24] 


\section{VIDEO 2: Mildred's Kiss}

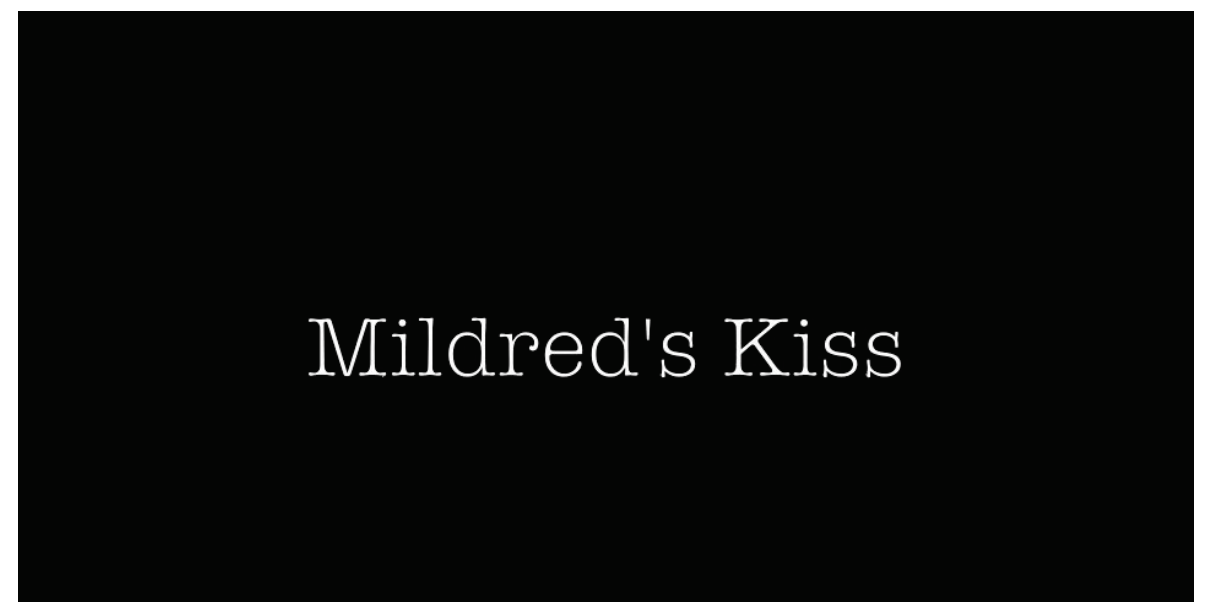

By superimposing Cain's words, I created a layered audio-visual text that brought the novel into the foreground and made the transgressive aspects of Mildred Pierce as maternal melodrama explicit. Paratextual material was visualised as part of the miniseries rather than 'outside'. I hoped that reading the words synchronously with viewing/listening to the images would unsettle the consensus and move the debate beyond issues of adaptation, but I also wanted to retain the emotive power of the images and soundtrack, and intensify the erotic impact of the kiss.[25] Overlaying the novel onto the miniseries also intimated the operations of multiple authorship involved in adaptation. In the process of making the Mildred's Kiss video, I came closer to understanding Haynes's use of performance and subtext. In replaying the scene several times to get technical matters right, I noticed the change in the lighting as Mildred's shadow falls over Veda, and the way the music and Edita Gruberová's soprano voice rise to a crescendo as Mildred's lips meet Veda's. Together with Kate Winslet's performance-as she moves in for the kiss in huge close-up, she pulls back her hair, then hesitates as her eyes travel over Veda's face, opening her mouth slightly when she kisses her on the lips — this eroticises the moment.

As a result, I was moved to make another video essay of that moment-Mildred's Kiss: A Maternal Melodrama.[26] In this case I omitted the scrolling text and slowed down the kiss, substituting a version of the 'Casta Diva' aria performed by Joan Sutherland on the soundtrack. To my ears, the Gruberová rendition used by Haynes sounds more desperate and hysterical, in tune with the novel, while Sutherland's voice overflows with longing and loss, evoking the melancholy of the Demeter/Persephone myth. In the aria, Norma sings to her lost love, urging him to return to her; in English translation, the words call up archaic natural imagery and profound passion as Norma begs her lover four times to come back.[27] Played over the Mildred/Veda kiss, the 
aria's connection to the myth becomes even stronger; Norma's yearning is displaced on to Mildred's desire for her daughter, with the crescendo at the moment of the kiss suggesting sexual climax.[28]

\section{VIDEO 3: Mildred's Kiss: A Maternal Melodrama}

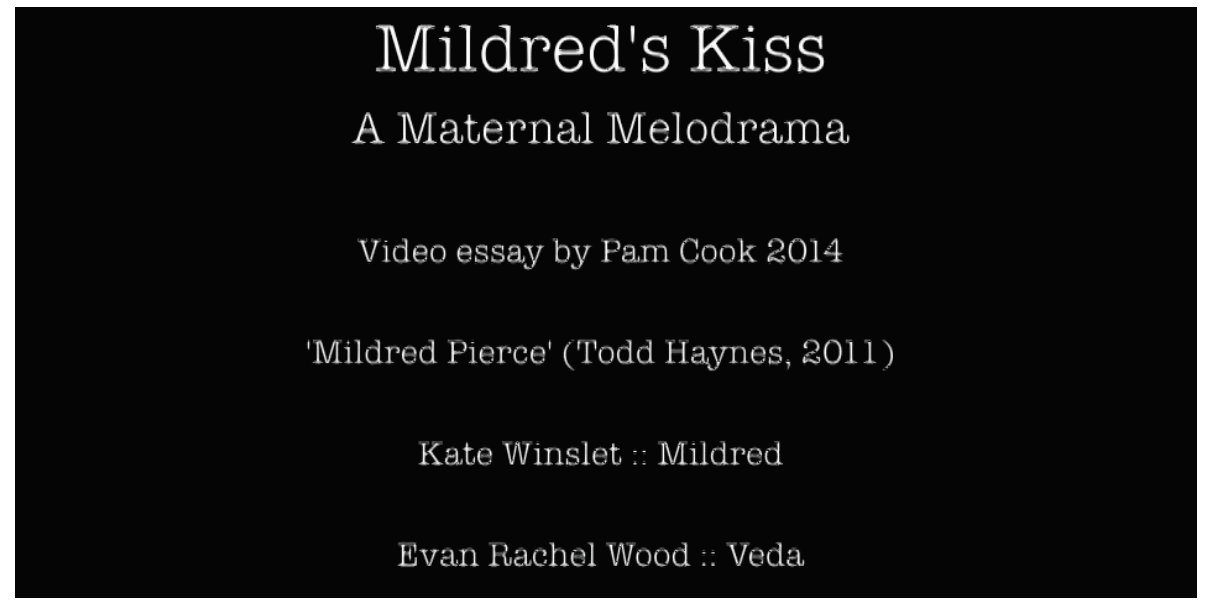

One of my aims was to draw attention to the power of subtext; in that respect the scene contains many less-obvious meanings. In addition to those placed in the miniseries by Haynes and those highlighted in the video essay, there are others deriving from paratexts available to be deciphered, among them Evan Rachel Wood's well-publicised bi-sexuality and James M. Cain's acknowledged love of opera. Both audio-visual essays position maternal melodrama as emerging from textual interaction and revision. In developing the videographic projects to produce critical commentary, an open-ended process of textual mutation took place, enabling an understanding of texts as mobile productions fashioned in a kind of serial activity. The concept of paratexts was crucial in bringing about these transformations, and in allowing reflections on reading methods, the boundaries of textual objects, and videographic procedures to emerge. The combination of written scholarship and the audio-visual essay helped to illuminate ways in which established techniques of research are shifting in the current media landscape.

My discussion of maternal melodrama as a fluid category constituted and given coherence by paratextual materials and trans-textual negotiations implies the adoption of self-reflexive forms of analysis that inscribe dialogic mechanisms within them. I have tried to demonstrate that approach here by making visible the processes, premises and investments of my research, which deploys a mix of scholarly and creative techniques. For example, as well as using written scholarship to open up issues around maternal 
melodrama, I explore the potential of videography to carry out detailed examination while reflecting on my interpretive methods and personal motivations.

In the context of the resurgence of cinephilia and intensified focus on close perusal of moving images, Genette's emphasis on the importance of paratexts to the reading process, and their role in producing new objects, takes on renewed relevance. Moreover, his study indicates that the materials on which we base arguments and deductions cannot be taken for granted as neutral or transparent, any more than our research methods and conclusions. This does not mean that textual analysis that works on decoding the meanings of a self-contained film or other object should be abandoned; indeed, it plays a valuable and necessary role in research practice. But Genette's work points the way to a mode of scholarly engagement that allows for the possibility of reconfiguring 'the text' and prevailing critical categories in light of recent technological and cultural developments. Rather than regret the loss of a unified textual entity, which is in any case a fabricated phenomenon, we might positively embrace the principle of interactivity and open up for discussion the trans-textual operations between diverse media, documents and artefacts as analytical tools in moving-image research. 


\section{ACKNOWLEDGEMENT}

Thanks to the participants in the Maternal Melodrama symposium at the University of Kent on 3 June 2014, especially Tamar Jeffers McDonald, Cecilia Sayad, Catherine Grant and Elizabeth Cowie. Thanks also to those who contributed to the discussion at the University of Sussex research seminar on 8 October 2014.

\section{SUGGESTED CITATION}

Cook, Pam. 'Text, Paratext and Subtext: Reading Mildred Pierce as Maternal Melodrama', SEQUENCE: Serial Studies in Media, Film and Music, 2.2, 2015. ISSN 2052-3033 (Online).

Online at: http://reframe.sussex.ac.uk/sequence2/archive/sequence-2-2/

\section{COPYRIGHT NOTICE}

\section{Copyright (C) 2015 Pam Cook}

Pam Cook is the copyright holder of the above text. In any future references to or uses of the above version of the written work (including the screenshot illustration), please also acknowledge SEQUENCE, 2.2, 2015 as its first place of publication. The three video essays embedded above have been shared by Pam Cook under a Creative Commons Attribution-NonCommercial-ShareAlike-3.0 Unported License (CC BY-NCSA 3.0).

SEQUENCE is a REFRAME publication. 


\section{REFERENCES}

Bachofen, J. J. (1967), Myth, Religion and Mother Right, trans. Ralph Mannheim, Princeton: Princeton University Press.

Butler, Judith (2006), Gender Trouble: Feminism and the Subversion of Identity, New York and Abingdon: Routledge.

Cain, James M. (1941), Mildred Pierce, New York: Alfred A. Knopf.

Churchwell, Sarah (2011), 'Re-reading: Mildred Pierce by James M. Cain', Guardian Books section, 24 June.

Cook, Pam (2013), 'Beyond Adaptation: Mirrors, Memory and Melodrama in Todd Haynes's Mildred Pierce', Screen, 54 (3), Autumn.

Cook, Pam (2014), 'Word vs. Image: Making Mildred's Kiss (2013)', Reframe: The Audiovisual Essay: Practice and Theory in Videographic Film and Moving Image Studies, September.

'Dossier on Melodrama' (1977), Screen, 18 (2).

Elsaesser, Thomas (1991), 'Tales of Sound and Fury: Observations on the Family Melodrama', in Marcia Landy (ed.), Imitations of Life: A Reader on Film \& Television Melodrama, Detroit: Wayne State University Press.

Genette, Gérard (1991) 'Introduction to the Paratext', trans. Marie Maclean, New Literary History, 22 (2), Spring.

Genette, Gérard (1997), Paratexts: Thresholds of Interpretation, trans. Jane E. Lewin, Cambridge: Cambridge University Press.

Grant, Catherine (2014), 'The Marriages of Laurel Dallas. Or, The Maternal Melodrama of the Unknown Feminist Film Spectator', Mediascape, Fall. Online at: http://www.tft.ucla.edu/mediascape/Fall2014_MarriagesMelodrama.html

Gray, Jonathan (2010), Show Sold Separately: Promos, Spoilers and Other Media Paratexts, New York: New York University Press.

Holquist, Michael (1981) (ed.), The Dialogic Imagination: Four Essays by M. M. Bakhtin, trans. Carol Emerson and Michael Holquist, Austin: University of Texas Press.

Jacobs, Lea (2009), 'Unsophisticated Lady: The Vicissitudes of the Maternal Melodrama in Hollywood', Modernism/Modernity, 16 (1), January.

McCracken, Ellen (2013), 'Expanding Genette's Epitext/Peritext Model for Transitional Electronic Literature: Centrifugal and Centripetal Vectors on Kindles and iPads', Narrative, 21 (1), January.

Moretti, Franco (1983), 'Kindergarten', in Signs Taken for Wonders: On the Sociology of Literary Forms, London: Verso.

Neale, Steve (1986), 'Melodrama and Tears', Screen 27 (6).

Sanxay Holding, Elisabeth (1947), The Blank Wall, New York: Simon \& Schuster. 
Sobchack, Vivian (1996), 'Bringing It All Back Home: Family Economy and Generic Exchange', in Barry K. Grant (ed.), The Dread of Difference, Austin: University of Texas Press.

Tate, Gabriel (2011), 'Mother Dearest: An Interview with Todd Haynes', Time Out, 24 June.

Taubin, Amy (2011), 'Daughter Dearest', Artforum, March.

Thornham, Sue (2013), "'A Hatred So Intense...": We Need to Talk About Kevin, Postfeminism and Women's Cinema', SEQUENCE 2.1. Online at: http://reframe.sussex.ac.uk/sequence2/archive/sequence-2-1/

Truhler, Kimberly (2011), 'The Style Essentials: Joan Crawford Works Hard in 1945's Film Noir MILDRED PIERCE', GlamAmor, 30 March.

Viviani, Christian (1979), 'Qui est sans péché: Le mélo maternel dans le cinéma américain, 1930-39', in Maurice Roelens (ed.), Pour une histoire du mélodrame au cinéma, Les Cahiers de la Cinémathèque, no. 28, July.

\section{NOTES}

[1] See Sue Thornham, "'A Hatred So Intense...": We Need to Talk About Kevin, Postfeminism and Women's Cinema', Sequence 2.1 (2013). Online at: http://reframe.sussex.ac.uk/sequence2/archive/sequence-2-1/, accessed 21 January 2015.

[2] See Vivian Sobchack, 'Bringing It All Back Home: Family Economy and Generic Exchange', in Barry K. Grant (ed.), The Dread of Difference, Austin: University of Texas Press, 1996. Cited by Thornham.

[3] Thornham, "'A Hatred So Intense..."'.

[4] Ellen McCracken, 'Expanding Genette's Epitext/Peritext Model for Transitional Electronic Literature: Centrifugal and Centripetal Vectors on Kindles and iPads', Narrative 21 (1), January 2013: 105-24. Also see Jonathan Gray, Show Sold Separately: Promos, Spoilers and Other Media Paratexts, New York: New York University Press, 2010. Cited by McCracken.

[5] Genette uses the term 'trans-textual' in preference to Julia Kristeva's 'intertextual'. I follow Genette because his term evokes the transformative relationship between texts. For more on the dialogic approach, see Michael Holquist (ed.), The Dialogic Imagination: Four Essays by M. M. Bakhtin, trans. Carol Emerson and Michael Holquist, Austin: University of Texas Press, 1981.

[6] Gérard Genette, 'Introduction to the Paratext', New Literary History, 22 (2), Spring 1991: 261-72. Reprinted in translation by Marie Maclean from Seuils (Paris: Georges Borchardt Inc., 1987). See also English translation of Seuils by Jane E. Lewin: Paratexts: Thresholds of Interpretation, Cambridge: Cambridge University Press, 1997. 
[7] James M. Cain, Mildred Pierce, New York: Alfred A. Knopf, 1941; Mildred Pierce (Warner Bros, 1945, directed by Michael Curtiz); Mildred Pierce (HBO miniseries, 2011, directed by Todd Haynes).

[8] For example, Gabriel Tate, 'Mother Dearest: An Interview with Todd Haynes', Time Out, 24 June 2011. Online at: http://www.timeout.com/london/film/motherdearest-an-interview-with-todd-haynes, accessed 21 January 2015; Amy Taubin, 'Daughter Dearest', Artforum, March 2011. Online at: http://artforum.com/inprint/issue=201103\&id=27590, accessed 21 January 2015.

[9] Sarah Churchwell, 'Re-reading: Mildred Pierce by James M. Cain', Guardian Books section, 24 June 2011. Online at:

http://www.guardian.co.uk/books/2011/jun/24/mildred-pierce-sarah-churchwellrereading, accessed 21 January 2015.

[10] For example, Kimberly Truhler, 'The Style Essentials: Joan Crawford Works Hard in 1945's Film Noir MILDRED PIERCE', GlamAmor, 30 March 2011. Online at: http://www.glamamor.com/2011/03/last-nights-movie-joan-crawford-in.html, accessed 21 January 2015.

[11] Pam Cook, 'Beyond Adaptation: Mirrors, Memory and Melodrama in Todd Haynes's Mildred Pierce', Screen, 54:3, Autumn 2013: 378-87.

[12] Pam Cook, Maternal Overdrive (2014): https://vimeo.com/107828829

[13] Maternal Overdrive (Second Sight Films, 2005).

[14] Thomas Elsaesser, 'Tales of Sound and Fury: Observations on the Family Melodrama', in Marcia Landy (ed.), Imitations of Life: A Reader on Film \& Television Melodrama, Detroit: Wayne State University Press, 1991: 68-92; also 'Dossier on Melodrama', Screen, 18 (2), 1977: 113-18.

[15] Lea Jacobs, 'Unsophisticated Lady: The Vicissitudes of the Maternal Melodrama in Hollywood', Modernism/Modernity, 16 (1), January 2009: 123-140.

[16] Christian Viviani, 'Qui est sans péché: Le mélo maternel dans le cinéma américain, 1930-39', in Pour une histoire du mélodrame au cinéma, Les Cahiers de la Cinémathèque, no. 28, July 1979, edited by Maurice Roelens.

[17] Jacobs: 124.

[18] Catherine Grant has written about the legacy of this feminist scholarship and its impact on her videographic work in 'The Marriages of Laurel Dallas. Or, The Maternal Melodrama of the Unknown Feminist Film Spectator', Mediascape, Fall 2014. Online at: http://www.tft.ucla.edu/mediascape/Fall2014_MarriagesMelodrama.html, accessed 23 January 2015.

[19] Jacobs: 129.

[20] Haynes referred to my 1978 article 'Duplicity in Mildred Pierce' on more than one occasion. For example: 'Daughter Dearest: Amy Taubin Talks with Todd Haynes', Artforum, March 2011, online at:

https://artforum.com/inprint/issue=201103\&id=27590, accessed 22 January 2015. 
[21] Franco Moretti, 'Kindergarten', in Signs Taken for Wonders: On the Sociology of Literary Forms, London: Verso, 1983: 162. Quoted in Steve Neale, 'Melodrama and Tears', Screen 27 (6), 1986: 6-23, p. 8.

[22] J. J. Bachofen, Myth, Religion and Mother Right, trans. Ralph Mannheim, Princeton: Princeton University Press, 1967.

[23] Drawing on Irigaray and Lévi-Strauss among others, Judith Butler discusses the importance of the incest taboo and exogamy in transforming sex into gender in Gender Trouble: Feminism and the Subversion of Identity, New York and Abingdon:

Routledge, 2006: $55 \mathrm{ff}$.

[24] Pam Cook, Mildred's Kiss (2013): https://vimeo.com/110705895

[25] Pam Cook, 'Word vs. Image: Making Mildred's Kiss (2013)', The Audiovisual Essay: Practice and Theory in Videographic Film and Moving Image Studies, September 2014. Online at: http://reframe.sussex.ac.uk/audiovisualessay/reflections/intransition-13/pam-cook/, accessed 23 January 2015.

[26] Pam Cook, Mildred's Kiss: A Maternal Melodrama (2014): https://vimeo.com/110791691

[27] Vincenzo Bellini, 'Casta Diva' aria from Norma (1831). Translated into English at: http://www.aria-database.com/search.php?individualAria=356, accessed 23 January 2015.

[28] It is worth noting that Norma contemplates infanticide after her lover betrays her, which connects the opera with the adult strand of maternal melodrama to which Mildred Pierce belongs. 